\title{
Significance of the Disabled-Friendly Architecture at Community College
}

\author{
Nur Farhana Mustahidin ${ }^{1 *}$, Zaharilah Abdul Kadir², Muhammad Aznor Bin Abdul
}

$\mathrm{Aziz}^{3}$

\author{
${ }^{1}$ Department of Building Construction Technology and Engineering Department, \\ Jelebu Community College, Negeri Sembilan \\ ${ }^{2}$ Teacher Education Institute Raja Melewar Campus Seremban Negeri Sembilan \\ ${ }^{3}$ Department of Engineering and Skills, Jelebu Community College, \\ Negeri Sembilan. \\ *Corresponding author. Email: nurfarhanasps@gmail.com
}

\begin{abstract}
This study was conducted to study the important aspects and factors of designing Community College architecture which offers Special Skills program for Students with Disabilities and this study can be used to Community College as well as all educational institutions in Malaysia to become disabled-friendly.

According to the findings of Hasnah (2009), less physical access to disabled people, including no dedicated zebra-crossing for the disabled, no lanes or ramps, no elevators or broken elevators, no special signage and no disabled toilets are among the obstacles found in daily activities of students with disabilities at an institution. The Persons with Disabilities Act 2008 (Act 685) of Part IV clarifies that persons with disabilities must have the right to access and use public facilities, amenities, services and public buildings open or provided to the public equally with persons with no disabilities. Therefore, the study was conducted to identify the accessibility factors that should be considered in the design of Community College architecture or the renovation work of existing Community College to make all Community College a disabled-friendly education hub in Malaysia.
\end{abstract}

Keywords: Community college, physical access, special skills, disabled-friendly education hub

\section{INTRODUCTION}

World Health Organization (WHO) stated that out of Malaysia's population; 32.6 million people (2019), $12 \%-15 \%$ of them are disabled people which is approximately 4.8 million people with disabilities in Malaysia. According to the Persons with Disabilities Act (2008), individuals with long-term physical, mental, intellectual or emotional disabilities who, when interacting with various barriers, can block the full and effective participation of such individuals in society are included in the disabled. Students with disabilities at Community College refer to students with learning disabilities, vision problems and hearing problems.

The government strongly encourages the disabled community to further their education. This is supported by the Department of Developmental Disabilities (JPOKU), which also provides financial assistance to all students with disabilities pursuing studies at Public Higher Learning Institution (IPTA), Private Higher Learning Institution (IPTS); approved by Ministry of Education, Polytechnic and Community College under the Ministry of Higher Education. According to the findings of Hasnah (2009), less physical access to disabled people, including no dedicated zebra-crossing for the disabled, no lanes or ramps, no elevators or broken elevators, no special signage and no disabled toilets are among the obstacles found in daily activities of students with disabilities at an institution.

There are several Community Colleges throughout Malaysia offering Special Skills program for students with disabilities in the Department of Polytechnic and Community College (2019). These are:

1. Jelebu Community College for Community College Certificate (Food Processing Basics);

2. Selayang Community College for Community College Certificate (Culinary Basics);

3. Bayan Baru Community College for Community College Certificate (Pastoral Basics);

4. Sungai Siput Community College for Community College Certificate (Information Technology);

5. Paya Besar Community College for Community College Certificate (Photography Basics); 
6. Tampin Community College for Community College Certificate (Fish Decorations);

7. Masjid Tanah Community College for Community College Certificate (Food and Landscape);

8. Kuching Community College for Community College Certificate (Creative Sewing Basics).

Utusan Borneo/Sarawak (29 Julai 2018)

Educational institutions for students with disabilities should be conducive to making this group comfortable and able to enjoy the same environment and educational facilities as other students. This is in line with the national aspiration of higher education to produce excellent people regardless of geography, gender or socioeconomic background of the Malaysian Education Development Plan (Higher Education) - PPPM (PT) 2015-2025.

In this regard, the Community College offers a Certificate of skills program for students with disabilities as an educational hub that provides exposure to technical and vocational training for further study. However, according to the findings of Intan Shazila Samsudin and Munirah Abdul Rahim (n.d), the management of the Department of Polytechnic and Community College Education (JPPKK) should provide funding to the college to build, develop and upgrade physical and sensory facilities to establish a Community College as a freelance campus (barrier free) and disabled-friendly.

\section{Objective}

Identify aspects and factors that are important when designing a Community College architecture that offers special skills for disability students.

\section{METHOD}

This study is an action research. According to Hopkins (1993), the action research framework is most appropriate for participants who recognize the existence of shortcomings in their educational activities and who would like to adopt some initial stance in regard to the problem, formulate a plan, carry out an intervention, evaluate the outcomes and develop further strategies in an iterative fashion. In a nutshell, action research is characterized by those constraints and strengths given a research methodology intended to be a workable technique.

\section{Research Methodology}

This study is using Qualitative Methods based on PDCA Model. The PDCA Model :

1. Plan:

Analysing problems -

a) Is the design of Community College architecture can be accessible to disabled people? b) Are the existing Community College in Malaysia suitable to be disabled-friendly education hub?

Solutions -

a) Identify the accessibility factors that should be considered in the design of Community College architecture.

b) Identify the renovation work of existing Community College to make all Community College a disabled-friendly education hub in Malaysia.

2. Do:

Data collection - Five participants from different backgrounds.

Data analysis - Through observations and interviews.

3. Check:

Results - all participants suggested that the management of the Department of Polytechnic and Community College Education (JPPKK) should provide funding to the college to build, develop and upgrade physical and sensory facilities to establish a Community College as a freelance campus (barrier free) and disabledfriendly.

4. Action:

Follow-up action - the purpose of action research is to take action to improve effectiveness. This can be done by changing the practices after consider the study proposal. In this step, a plan of action was created to address the problem.

\section{FINDING AND DISCUSSION}

Finding(s)

This study is an action study involving observation methods and interviews. From the interviews, these are the findings:

Participant 1: Able and disabled people are considered as one community I refer as inclusivity. So, disabled people should be experiencing the same facilities as able people.

Participant 2: The demand for community colleges was high but the community colleges were tied to a ratio of one lecturer to five students due to the shortage of classes and workshops.

Participant 3: Enhancing the infrastructure to accommodate the disabled as a student at Community College is only a small expense compared to the losses incurred by the Government as Community College recruitment norms have not been met since 2015 . 
Participant 4: Community College Malaysia should feel the need and become the place I called as "a place for everybody".

Participant 5: I am suggesting that Community College Malaysia become a Special Centre for Special Community (SCSC) that provides education, healthcare, career, a place for everybody especially below 40 and train the disabled to become trainers.

\section{$\operatorname{Discussion}(\mathbf{s})$}

The findings show that the facilities in Community College Malaysia should be uplifting to fulfill the needs for everybody including disabled group. 103 Community Colleges in Malaysia need to facilitate with a correct size of ramps, elevators and more importanty, should be accesible by disabled throughout the entire compound. Furthermore, the demand from disabled group to study in Community College is high. Then, the action must be taken quickly in order to cater for the increasing demand.

On the other hand, Government had suffered losses of approximately RM75 million as Community College recruitment norms have not been met since 2015. Hence, if $30 \%$ of the empty norms can be accomodated by disabled people, Malaysian Government can save about RM75 millions yearly since the calculation is based on RM15,000 (government subsidised) per student times 5000 placements in 103 Community Colleges through out the country which has not been filled up every year.

The Persons with Disabilities Act 2008 (Act 685) of Part IV clarifies that persons with disabilities must have the right to access and use public facilities, amenities, services and public buildings open or provided to the public equally with persons with no disabilities. Therefore, the study was conducted to identify the accessibility factors that should be considered in the design of Community College architecture or the renovation work of existing Community College to make all Community College a disabled-friendly education hub in Malaysia.

According to Maszlee Malik (2019), Community College Malaysia should play as an important role in educating disabled and share the knowledge of lifelong learning through Technical and Vocational Education and Training (TVET) as "no one gets left behind".

\section{CONCLUSION}

As a conclusion, this study suggested to Department of Polytechnic and Community College Education (JPPKK) to conduct a feasibility study as an action plan to fulfill the research objective. Hence this study has looked at all the important aspects and factors when designing a Community College architecture that offers a special skills program for students with disabilities. The results of the study are expected to serve as a guide for the management of Department of Polytechnic and Community College Education (JPPKK) in designing the Community College which is still in the preconstruction phase and complete and renovate the infrastructure for the existing Community College. Therefore, it is proposed that the Community College will become the One Stop Center in Malaysia for able and disable students to continue their studies for the purpose of living sustainably as well as managing their daily life skills.

\section{REFERENCES}

Akta Orang Kurang Upaya 2008 (Akta 685)

Intan Shazila Samsudin, Munirah binti Abdul Rahim (n.d.). Kolej Komuniti Sebagai Hub Melanjutkan Pelajaran Bagi Golongan Orang Kelainan Upaya $(O K U)$ : Satu Tinjauan.

Jabatan Pendidikan Politeknik dan Kolej Komuniti (2019). Retrieved August 22, 2019, from website: http://www.mypolycc.edu.my/

Jabatan Pembangunan Orang Kurang Upaya (JPOKU). Senarai Kemudahan Dan Keistimewaan Bagi Orang Kurang Upaya. Jabatan Kebajikan Masyarakat.

Kemmis, S., \& McTaggart, R. (Eds.). (1990b). The action research reader. Victoria: Deakin University.

Pelan Pembangunan Pendidikan Malaysia (Pendidikan Tinggi) - PPPM (PT) 2015-2025.

Toran, H., Yasin, M. H. M., Tahar, M. M., \& Sujak, N. (2009). Sokongan dan halangan yang dihadapi pelajar-pelajar kurang upaya di sebuah institusi pengajian tinggi di Malaysia. AJTLHE: ASEAN Journal of Teaching and Learning in Higher Education, 1(2), 18-29.

Utusan Borneo (Sarawak) (29 Julai 2018). Program pengajian Kolej Komuniti untuk pelajar OKU akan ditambah. Retrieved August 14, 2019, from website: https://www.pressreader.com/ 